\title{
The Use of Antihypertensive Medicines in Primary Health Care Settings
}

\author{
Marc Twagirumukiza1,2, Jan De Maeseneer2, Thierry Christiaens ${ }^{1,2}$, \\ Robert Vander Stichele ${ }^{1}$ and Luc Van Bortel ${ }^{1}$ \\ ${ }^{1}$ Heymans Institute of Pharmacology, Ghent University, Ghent, \\ ${ }^{2}$ Department of Family Medicine and Primary Health Care, Ghent University, Ghent, \\ Belgium
}

\section{Introduction}

This chapter is drawing out the patterns and evidences for the use of antihypertensive medicines in general and in primary health care settings in particular. It presents the overview of the recent advances in clinical effectiveness of the antihypertensive medicines, but also document the implication for management of hypertension in low level health facilities. The discussions are based on the new evidences from clinical practice, reviews and meta-analysis studies.

The chapter as whole is written from a comprehensive health care system development rather than from a purely medicines description perspective. Finally the authors do not intend to substitute the students or prescribers vademecum or medicines' handbooks but providing an update in their daily questions when comes the issue of whom, what (and with what) to treat as far as arterial hypertension is concerned, in primary health care settings.

\section{Rationale, objectives and methods}

Hypertension, also known as "high blood pressure" is currently the major risk factor for coronary heart disease (Roger VL. and others 2011) and cerebrovascular disease (stroke) (Roger VL. and others 2011; Twagirumukiza and others 2011). Already known as significant public health problem worldwide particularly in western societies (Kearney and others 2005), hypertension has been documented recently as real health threat in developing countries as well (Kearney and others 2005; Twagirumukiza and others 2011). Hypertension remains the leading reason for office visits in primary care (Pittrow and others 2004) in some western countries in contrast with developing countries where awareness is still low and where hypertensive patients reach health facilities rather for complications. This situation in developing countries, emphasizes the need of other approaches and strategies to avert the Non Communicable Diseases (NCDs) in general and the arterial hypertension morbidity and mortality in particular by targeting the lower level of the health system chain (De Maeseneer J. and others 2011).

On the other side, despite the availability of a wide range of antihypertensive drugs (Van Bortel and others 2011), blood pressure has remained poorly controlled in a majority of health 
care settings, particularly in low resource settings. The access to medicines is highly driven by the availability and the cost of these drugs and strongly influences the prescription and usage patterns which in the end affect control of blood pressure(Twagirumukiza and others 2010). The rational use of available resources and the integration of the management strategies at primary health care level (De Maeseneer J 2009) have been advocated as key point of improving hypertension treatment (Twagirumukiza and Van Bortel 2011).

The aim of this chapter summarize the current knowledge on the use of antihypertensives in primary care and to provide an update to prescribers and health professionals in their daily questions about whom-and-how to treat -as far as arterial hypertension is concerned.

\section{Epidemiology of hypertension}

Arterial hypertension (HT) refers to a permanently and abnormally elevated arterial blood pressure. Arterial blood pressure (BP) corresponds to the force exerted by the circulating blood on the walls of blood vessels, and constitutes one of the cardinal vital clinical signs (Nichols WW. and others 2011). Hypertension can be classified either essential (primary) or secondary. Essential hypertension indicates that no specific medical cause can be found to explain a patient's condition. Secondary hypertension indicates that the high blood pressure is a result of (i.e., secondary to) another condition, such as kidney disease or tumours (pheochromocytoma among others). In current usage, the word "hypertension" once used without a qualifier will refers to essential systemic, arterial hypertension.

According to the World Health Organization (WHO) (World Health Organization and others 2004), hypertension is one of 7 diseases composing the entity of "cardiovascular diseases" (CVDs). This entity list includes, besides hypertension, coronary heart disease, cerebrovascular disease, peripheral artery disease, rheumatic heart disease, congenital heart disease and heart failure (Lopez and others 2006; World Health Organization and others 2004). By its target organ damage (TOD) hypertension remains an important cause of coronary heart disease, cerebrovascular disease, peripheral artery disease, and heart failure, which counts together with congenital heart disease for more than $75 \%$ of the CVDs morbimortality worldwide. The epidemiology of hypertension is therefore linked to CVDs and within this chapter, is considered both as a disease and as a risk factor for other CVDs.

Cardiovascular diseases, especially hypertension and related risk factors are of real health concern worldwide (Lawes and others 2008). Currently, the majority of hypertensive people live in developing regions (Kearney and others 2005), where their number is presumed to increase in coming decades (Kearney and others 2005), which inevitably will lead to a higher burden of cardiovascular diseases (Kearney and others 2005; Murray and Lopez 1997). Within a context of limited data on the burden of hypertension and other chronic diseases in many developing countries (Murray and Lopez 1997), those diseases are very often considered as uncommon and therefore they are rarely addressed by policy makers (Unwin and others 2001) who are very often focused on a well described predominance of infectious diseases in these regions (Unwin and others 2001).

Nevertheless, hypertension should be considered of great economic importance also in developing countries and regions like in Latina America, South Asia and sub-Saharan Africa, because it is frequently underdiagnosed, and frequently undertreated, as patients often cannot afford treatment. In such situations, the complications of hypertension are 
more frequent and more severe: mainly heart failure (Mensah 2003) and stroke (Mufunda J and others 2006). In addition if developing world inhabitants survive to adulthood, hypertension-related disease may be the major cause of premature mortality (Twagirumukiza and others 2009b). The prevalence of hypertension has been well described worldwide (Kearney and others 2005) and in sub-Saharan Africa (Twagirumukiza and others 2011). The current figures and their projections remain overwhelming. Currently around 972 million people have hypertension worldwide (rising up to 1.6 billion in 2025) and more than $65 \%$ of them are in developing countries (Kearney and others 2005). The 2008 number of hypertensives in sub-Saharan Africa is estimated at 74.7 million (increasing by $68.0 \%$ in 2025(Twagirumukiza and others 2011)). The prevalence of hypertension in this region is estimated at $16.2 \%$, being higher in urban than in rural regions (Twagirumukiza and others 2011). This prevalence adjusted to WHO standard population is similar to the prevalence in western countries (Table 1 ).

Table 1 shows that although the prevalence of hypertension was lower in sub-Saharan Africa than in England and USA, the prevalence of hypertension adjusted to the WHO standard population was higher in sub-Saharan Africa than in England and tended to be higher than in USA. However, the analysis of age-specific prevalence data shows that the hypertension prevalence is higher at younger ages (up to 35 years) in sub-Saharan Africa compared to the western countries, indicating that hypertension starts at earlier age in subSaharan Africa. The prevalence in old people is lower in sub-Saharan Africa than in western country. The plausible explanation is linked to low accessibility to treatment: by lacking adequate treatment people with hypertension at younger age died in earlier ages (around 45-54 years). People with hypertension at older age are new cases or survivors.

There are evidences (Twagirumukiza and others 2011) of a clear difference in hypertension prevalence between countries. Different factors like diet habits (i.e. salt consumption) and genetic predisposition may play a role. As expected the prevalence of hypertension also increases with age and that prevalence was $50.7 \%$ higher in urban than in rural area. The influence of urbanization on hypertension was more pronounced in males than in females. These observations in rural versus urban areas are in line with other recent reports (Opie and Seedat 2005) reporting urban prevalence 1.5 to 2 times higher than rural ones. This difference can be influenced by the habits in rural which are dominated by routine field work as compared to urban lifestyle with more consumption of energy rich foods and a decrease in energy expenditure through less physical activity (Opie and Seedat 2005). However, modernisation (Dominguez and others 2006) may also transform rural settings themselves such as increasing use of automobiles leading to a decrease in physical activity, increasing overweight and obesity and more consumption of salt (Mufunda J and others 2006; Reddy and Yusuf 1998) and tobacco (Jha P and Chaloupka F 1999).

In sub-Saharan Africa setting, hypertension occurs earlier among adults of working age and its complications strike people at the top of their economic activity (Gaziano 2005; Twagirumukiza and others 2009b). Apart from the consequences on the quality of individual health, this leads to a large impact on a developing country's economic viability. In South Africa, for example, $2 \%$ to $3 \%$ of the country's gross national income, or roughly $25 \%$ of South African healthcare expenditures, was devoted to the direct treatment of cardiovascular disease (CVD) (Gaziano 2005; Pestana and others 1996). 


\begin{tabular}{|c|c|c|c|c|c|c|}
\hline \multirow[b]{2}{*}{ Age-range[a] } & \multicolumn{3}{|c|}{$\begin{array}{l}\text { Crude hypertension prevalence in \% } \\
\text { (number of diagnosed hypertensive people/sample size) }\end{array}$} & \multicolumn{3}{|c|}{$\begin{array}{l}\text { Statistical comparison test } \\
\text { p-value }\end{array}$} \\
\hline & [1]sub-Saharan Africa & [2] England & [3] USA & $\begin{array}{c}\text { Within } \\
\text { all }\end{array}$ & $\begin{array}{c}\text { sub- } \\
\text { Saharan } \\
\text { Africa } \\
\text { vs } \\
\text { England }\end{array}$ & $\begin{array}{c}\text { sub- } \\
\text { Saharan } \\
\text { Africa } \\
\text { vs } \\
\text { USA }\end{array}$ \\
\hline $15-34$ & $\begin{array}{c}6.9 \\
(19,366,486 / 281,419,841)\end{array}$ & $\begin{array}{c}4.2 \\
(33,461 / 798,390)\end{array}$ & $\begin{array}{c}6.0 \\
(178 / 2,971)\end{array}$ & $<0.001$ & $<0.001^{*}$ & $<0.001^{*}$ \\
\hline $35-44$ & $\begin{array}{c}17.1 \\
(12,788,663 / 74,689,253)\end{array}$ & $\begin{array}{c}12.3 \\
(60,128 / 487,692)\end{array}$ & $\begin{array}{c}16.0 \\
(135 / 846)\end{array}$ & $<0.001$ & $<0.001^{*}$ & NS \\
\hline $45-54$ & $\begin{array}{c}28.8 \\
(14,195,235 / 49,276,086)\end{array}$ & $\begin{array}{c}26.3 \\
(102,484 / 389,053)\end{array}$ & $\begin{array}{c}31.0 \\
(242 / 781)\end{array}$ & $<0.001$ & $<0.001^{*}$ & NS \\
\hline $55-64$ & $\begin{array}{c}44.0 \\
(13,886,165 / 31,526,626)\end{array}$ & $\begin{array}{c}45.8 \\
(162,533 / 355,094)\end{array}$ & $\begin{array}{c}48.0 \\
(312 / 650)\end{array}$ & 0.045 & 0.004 & NS \\
\hline$\geq 65$ & $\begin{array}{c}60.1 \\
(14,470,484 / 24,074,117)\end{array}$ & $\begin{array}{c}61.2 \\
(333,947 / 545,786)\end{array}$ & $\begin{array}{c}71.4 \\
(849 / 1,189)\end{array}$ & $<0.001$ & NS & $<0.001$ \\
\hline Overall & $\begin{array}{c}16.2 \\
(74,707,034 / 460,985,923)\end{array}$ & $\begin{array}{c}26.9 \\
(692,553 / 2,576,015)\end{array}$ & $\begin{array}{c}26.7 \\
(1,716 / 6,437)\end{array}$ & $<0.001$ & $<0.001$ & $<0.001$ \\
\hline $\begin{array}{l}\text { Prevalence } \\
\text { standardized for } \\
\text { WHO standard } \\
\text { population [4] }\end{array}$ & 22.3 & 18.4 & 21.6 & $<0.001$ & $<0.001^{*}$ & NS \\
\hline
\end{tabular}

[a] Age range for USA prevalence starts from 18 years, for England are from 16 years and for subSaharan Africa are from 15 years; [1] Results from a meta-analysis on the population-based studies(Twagirumukiza and others 2011); [2] Results from the Health Improvement Network (THIN) database \& Health Survey for England (HSE)(MacDonald and Morant 2008); [3] NHANES III continuous(Fields and others 2004); [4] WHO standard population adjusted prevalence; NS: Not statistically significant *sub-Saharan Africa is statistically higher.

Table 1. Comparison between sub-Saharan Africa pooled data and developed countries surveys.

\section{Management of hypertension in primary health care}

\subsection{Definitions challenges, and first drug choice}

Up from what level a blood pressure is considered as high or as hypertension has been a constant discussion over time. Since the relationship between blood pressure and adverse health effects displays a non-linear but continuous relationship (John KJ Li 2000), any classification of people into dichotomous categories ('normotensive' and 'hypertensive') as well as other blood pressure staging are arbitrary (Mancia and others 2007). Nevertheless, clinicians and other health care workers often must make essentially dichotomous decisions (Birkett 1997) (e.g. whether or not to start pharmacological treatment for elevated blood pressure). The basis for classifying people into 'hypertensive' and 'normotensive' groups is encouraged by a consideration of 'excess risk' or by proven treatment benefit in clinical trials (Birkett 1997) for a certain level of blood pressure. 
The definition of hypertension is then based on the potential of blood pressure to become a risk for cardiovascular events (Khosla and Black 2006). But this evaluation of potential risk has been improving in time and cut-offs have been lowered progressively. Previously, hypertension started at a cut-off SBP/DBP value of $160 / 95 \mathrm{mmHg}$, whereas the current standard is $140 / 90 \mathrm{mmHg}$. The current definition of hypertension which is unanimously agreed on by USA Joint National Committee on Detection, Evaluation, and Treatment of High Blood Pressure (JNC7)(Chobanian and others 2003), European Society of Hypertension (ESH) and of the European Society of Cardiology (ESC)(Mancia and others 2007) and World Health Organization (WHO)(Chalmers and others 1999) is : SBP $\geq \mathbf{1 4 0} \mathbf{m m H g}$ and/or DBP $\geq$ 90 $\mathrm{mmHg}$ and/or being on blood pressure lowering medication(Chalmers and others 1999; Chobanian and others 2003; Mancia and others 2007). These cut-off values are even lower in high risk population (diabetes or renal failure). Different thresholds have been given for different types of measurements (Table 2).

\begin{tabular}{lll} 
Situations & SBP & DBP \\
\hline \hline Office or clinic & 140 & 90 \\
Ambulatory 24-hour & $125-130$ & 80 \\
Day & $130-135$ & 85 \\
Night & 120 & 70 \\
Home & $130-135$ & 85 \\
\hline \hline
\end{tabular}

Table 2. Different Blood pressure thresholds (mmHg)(Mancia and others 2007)

In daily practice, the blood pressure has also been splitted up into grades to help management. In this chapter, the most recent (2007) classification (Mancia and others 2007) will be used as a reference.

\begin{tabular}{|c|c|c|c|}
\hline $\begin{array}{l}\text { SBP/DBP } \\
\text { (mmHg) }\end{array}$ & WHO/ISH (2003) & JNC-7 (2003) & ESH/ESC (2007) \\
\hline$<<120 / 80$ & - & Normal & Optimal \\
\hline $120-129 / 80-84$ & - & \multirow[t]{2}{*}{ Pre-hypertension } & Normal \\
\hline $130-139 / 85-89$ & - & & High normal \\
\hline $140-159 / 90-99$ & Hypertension grade 1 & Hypertension stage 1 & Hypertension grade 1 (mild) \\
\hline 160-179/100-109 & Hypertension grade 2 & \multirow[t]{2}{*}{ Hypertension stage 2} & $\begin{array}{l}\begin{array}{l}\text { Hypertension grade } 2 \\
\text { (moderate) }\end{array} \\
\end{array}$ \\
\hline$\geq 180 / 110$ & Hypertension grade 3 & & Hypertension grade 3 (severe) \\
\hline$* * \geq 140 /<90$ & - & - & Isolated systolic hypertension \\
\hline
\end{tabular}

JNC-7: the Seventh report of the Joint National Committee on prevention, detection, evaluation, and treatment of high blood pressure (JNC-7)(Chobanian and others 2003). ESH/ESC: the European Society of Hypertension - European Society of Cardiology(Mancia and others 2007). WHO/ISH: the World Health Organization/ International Society of Hypertension(Whitworth 2003). Note that hypertension is defined as SBP/DBP of 140/90 $\mathrm{mmHg}$ according to the three recommendations(Chemla 2006). When a patient's systolic and diastolic blood pressure fall into different categories, the higher category should apply.

Table 3. Recent classifications and staging of Systolic (SBP) / Diastolic (DBP) Blood Pressure levels 
In some patients, medical office blood pressure is persistently elevated while ambulatory or home blood pressure, are within their normal range. This condition is widely known as 'white coat hypertension' (Mancia and others 2007). Inversely the hypertension found with ambulatory blood pressure measurement but not in clinic is known as "masked hypertension" (Papadopoulos and Makris 2007).

\subsection{Cardiovascular risk evaluation}

In aim to decide which drug to use, the patient risk needs to be evaluated. Many algorithms and charts have been released and some health professionals may be even confused. Authors argue that estimating risk is not the problem, but using it to tailor treatment to individuals is (Christiaens 2008). This section will not document all available charts in details , but will put forward the most useful risk assessment tool in the field.

Historically, hypertension guidelines focused on blood pressure values as the only or main variables determining the need and the type of treatment (Chobanian and others 2003). The current approach (Mancia and others 2007) emphasizes that diagnosis and management of hypertension should be related to quantification of total (or global) cardiovascular risk. List 1 shows those cardiovascular risk factors, including hypertension.

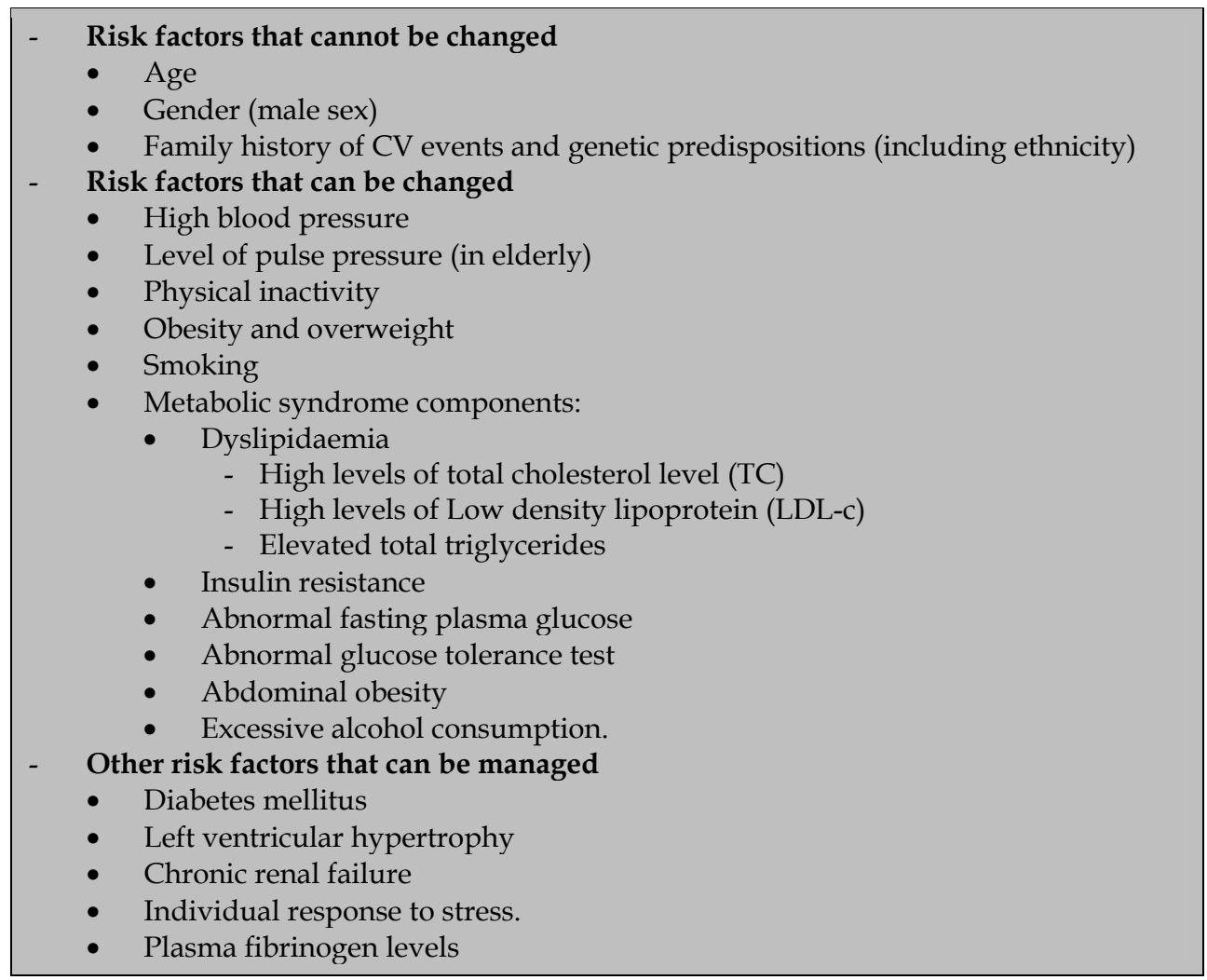

List 1. List of cardiovascular(CV) risk factors(Mancia and others 2007) 
It has been proposed (Mancia and others 2007) that the management of hypertension should be based on two criteria, i.e. (1) the level of systolic and diastolic blood pressure, and (2) the level of added cardiovascular risk (List 1). Thus, the management of hypertension has been shifted from viewing and treating it as an isolated element to a more comprehensive approach of cardiovascular risk stratification that takes into account other cardiovascular risk factors like cholesterol, smoking, diabetes and metabolic syndrome (MS). In addition, subclinical organ damage (List 2) is considered as higher added risk showing that risk factors led to organ damage.

The cardiovascular risk stratification table (Table 4) is obtained by combination of presence of risk factors, target organ damage and diabetes and the levels of systolic and diastolic blood pressure.

We have to keep in mind that many other risk tables have been developed as well. Hippisley-Cox and colleagues have developed and validated the second version of the QRISK cardiovascular disease risk algorithm (QRISK2), an attempt to more accurately estimate cardiovascular risk in patients from different ethnic groups in England and Wales(Christiaens 2008). The SCORE tables used the same risk factors to calculate corrected European cardiovascular mortality (Christiaens 2008). More recently the ASSIGN (Christiaens 2008) and now the QRISK tables (Christiaens 2008) tried to incorporate some other known risk factors, especially deprivation and family history.

All attempts to make risk tables more accurate, as done by Hippisley-Cox and colleagues in the QRISK2 algorithm (Christiaens 2008) should be welcomed. However, this is not the key problem. We have to fundamentally rethink how to use risk tables when making treatment decisions in practice, taking into consideration the prescribing in healthy older people and the correct use of drugs.

Left Ventricular Hypertrophy (LVH):

- Electrocardiographic LVH (Sokolow-Lyon $>38 \mathrm{~mm}$; Cornell $>2440 \mathrm{~mm} * \mathrm{~ms}$ ) or:

- Echocardiographic LVH(LVMI M $\geq 125 \mathrm{~g} / \mathrm{m} 2, \mathrm{~W} \geq 110 \mathrm{~g} / \mathrm{m} 2)$

Carotid wall thickening (IMT $>0.9 \mathrm{~mm}$ ) or plaque

Carotid-femoral pulse wave velocity $(\mathrm{PWV})>12 \mathrm{~m} / \mathrm{s}$

Ankle/brachial BP index $<0.9$

Slight increase in plasma creatinine:

- $\quad \operatorname{Men}(\mathrm{M}):$ 115-133 $\mu \mathrm{mol} / \mathrm{l}(1.3-1.5 \mathrm{mg} / \mathrm{dl})$;

- Women (W): 107-124 $\mu \mathrm{mol} / 1(1.2-1.4 \mathrm{mg} / \mathrm{dl})$

- Low estimated glomerular filtration rate $\left(<60 \mathrm{ml} / \mathrm{min} / 1.73 \mathrm{~m}^{2}\right)$ or creatinine clearance $(<60 \mathrm{ml} / \mathrm{min})$

- Microalbuminuria 30-300 mg/24 h or albumin-creatinine ratio: $\geq 22(\mathrm{M})$ or $\geq 31(\mathrm{~W})$ $\mathrm{mg} / \mathrm{g}$ creatinine

*Adapted from “2007 ESC/ESH Recommendations" (Mancia and others 2007)

List 2. Sub-Clinical Organ Damage (OD) 


\begin{tabular}{|l|c|c|c|c|c|}
\hline \multirow{2}{*}{$\begin{array}{l}\text { Other risk factors, } \\
\text { OD or disease }\end{array}$} & \multicolumn{4}{|c|}{ Blood pressure levels (grades according the ESC/ESH Classification) in } \\
mmHg
\end{tabular}

*Adapted from “2007 ESC/ESH Recommendations" (Mancia and others 2007)

Notes and legends: SBP: systolic blood pressure; DBP: diastolic blood pressure; CV: cardiovascular;

HT: hypertension. Low, moderate, high and very high risk refer to 10 year risk of a CV fatal or non-fatal event. The term 'added' indicates that in all categories risk is greater than average.

OD: subclinical organ damage; MS: metabolic syndrome.

Table 4. Stratification of Cardiovascular Risk expressed as added cardiovascular risk

\subsection{Hypertension management strategies}

The treatment of hypertension itself is based on prevention measures (World Hypertension League 1992), non-pharmacological measures (Cooper and others 1998) and a pharmacological treatment (Dominguez and others 2006). Table 5 shows the advocated (Mancia and others 2007) therapeutic approach based on cardiovascular risk stratification as shown in Table 4.

\section{Preventive strategies}

Because of restrained economic conditions in the developing world, the greatest gains in controlling the Cardiovascular diseases epidemic lie in its prevention. In addition to prevention, awareness of having hypertensive is important. Efforts should be made to early detect hypertensive patients before irreversible organ damage, and to provide them with the best possible and affordable non-pharmacological and pharmacological treatment.

The preventive actions concern habits and lifestyle monitoring. Those include the important but relatively low cost preventive measures: reduction in dietary salt intake (Douglas and others 2003), and a greater awareness of the implications of obesity (Bovet and others 2002). There is good evidence that a reduction in salt intake reduces blood pressure and that black people are more sensitive than white people in this regard (Cappuccio and others 2000). Other measures as increased exercise (Opie and Seedat 2005), stopping smoking (Ambrose 
and Barua 2004) and limiting alcohol intake (Appel and others 2003) are all attainable and can help in control of the hypertension as well.

\begin{tabular}{|c|c|c|c|c|c|}
\hline \multirow[b]{2}{*}{$\begin{array}{l}\text { Other risk factors, } \\
\text { OD or disease }\end{array}$} & \multicolumn{5}{|c|}{ Blood pressure (grades according the ESC/ESH Classification) in $\mathrm{mmHg}$} \\
\hline & $\begin{array}{c}\text { SBP 120-129 } \\
\text { or } \\
\text { DBP 80-84 } \\
\text { (Normal) }\end{array}$ & \begin{tabular}{|c|} 
SBP 130-139 \\
or \\
DBP 85-89 \\
(High normal) \\
\end{tabular} & $\begin{array}{c}\text { SBP 140-159 } \\
\text { or } \\
\text { DBP 90-99 } \\
\text { (Grade } 1 \mathrm{HT} \text { ) }\end{array}$ & $\begin{array}{c}\text { SBP 160-179 } \\
\text { or } \\
\text { DBP 100-109 } \\
\text { (Grade 2 HT) }\end{array}$ & $\begin{array}{c}\mathrm{SBP} \geq \mathbf{1 8 0} \\
\text { or } \\
\text { DBP } \geq \mathbf{1 1 0} \\
\text { (Grade 3 HT) }\end{array}$ \\
\hline No other risk factors & $\begin{array}{c}\text { No BP } \\
\text { Intervention }\end{array}$ & $\begin{array}{c}\text { No BP } \\
\text { intervention }\end{array}$ & $\begin{array}{c}\text { Lifestyle } \\
\text { changes } \\
\text { (several } \\
\text { months) then } \\
\text { drug } \\
\text { treatment } \\
\text { if BP } \\
\text { uncontrolled }\end{array}$ & $\begin{array}{c}\text { Lifestyle } \\
\text { changes } \\
\text { (several } \\
\text { months) then } \\
\text { drug } \\
\text { treatment } \\
\text { if BP } \\
\text { uncontrolled }\end{array}$ & $\begin{array}{c}\text { Lifestyle } \\
\text { changes } \\
\quad+ \\
\text { Immediate } \\
\text { drug } \\
\text { treatment }\end{array}$ \\
\hline $1-2$ risk factors & $\begin{array}{l}\text { Lifestyle } \\
\text { changes }\end{array}$ & $\begin{array}{l}\text { Lifestyle } \\
\text { changes }\end{array}$ & $\begin{array}{c}\text { Lifestyle } \\
\text { changes } \\
\text { (several } \\
\text { months) then } \\
\text { drug } \\
\text { treatment } \\
\text { if BP } \\
\text { uncontrolled }\end{array}$ & $\begin{array}{c}\text { Lifestyle } \\
\text { changes } \\
\text { (several } \\
\text { months) then } \\
\text { drug } \\
\text { treatment } \\
\text { if BP } \\
\text { uncontrolled }\end{array}$ & $\begin{array}{c}\text { Lifestyle } \\
\text { changes } \\
+ \\
\text { Immediate } \\
\text { drug } \\
\text { treatment }\end{array}$ \\
\hline $\begin{array}{l}3 \text { or more risk } \\
\text { factors, } \\
\text { MS or OD }\end{array}$ & $\begin{array}{l}\text { Lifestyle } \\
\text { changes }\end{array}$ & \begin{tabular}{|c|}
$\begin{array}{c}\text { Lifestyle } \\
\text { changes } \\
+ \\
\text { Consider drug } \\
\text { treatment }\end{array}$ \\
\end{tabular} & $\begin{array}{c}\text { Lifestyle } \\
\text { changes } \\
+\end{array}$ & $\begin{array}{c}\text { Lifestyle } \\
\text { changes } \\
+\end{array}$ & $\begin{array}{c}\text { Lifestyle } \\
\text { changes } \\
+\end{array}$ \\
\hline Diabetes & $\begin{array}{l}\text { Lifestyle } \\
\text { changes }\end{array}$ & \begin{tabular}{|c}
$\begin{array}{c}\text { Lifestyle } \\
\text { changes } \\
+ \\
\text { Drug treatment }\end{array}$ \\
\end{tabular} & $\begin{array}{c}\text { Drug } \\
\text { treatment }\end{array}$ & $\begin{array}{l}\text { Drug } \\
\text { treatment }\end{array}$ & $\begin{array}{l}\text { Immediate } \\
\text { drug } \\
\text { treatment }\end{array}$ \\
\hline $\begin{array}{l}\text { Established CV } \\
\text { or renal disease }\end{array}$ & $\begin{array}{c}\text { Lifestyle } \\
\text { changes } \\
+ \\
\text { Immediate } \\
\text { drug } \\
\text { treatment } \\
\end{array}$ & $\begin{array}{c}\text { Lifestyle } \\
\text { changes } \\
+ \\
\text { Immediate } \\
\text { drug treatment }\end{array}$ & $\begin{array}{c}\text { Lifestyle } \\
\text { changes } \\
\quad+ \\
\text { Immediate } \\
\text { drug } \\
\text { treatment } \\
\end{array}$ & $\begin{array}{c}\text { Lifestyle } \\
\text { changes } \\
+ \\
\text { Immediate } \\
\text { drug } \\
\text { treatment }\end{array}$ & $\begin{array}{c}\text { Lifestyle } \\
\text { changes } \\
\quad+ \\
\text { Immediate } \\
\text { drug } \\
\text { treatment }\end{array}$ \\
\hline
\end{tabular}

Notes and legends: SBP: systolic blood pressure; DBP: diastolic blood pressure; CV: cardiovascular; HT: hypertension. OD: subclinical organ damage; MS: metabolic syndrome.

Table 5. Therapeutic approach for hypertension in adults [Adapted from 2007 ESC/ESH Recommendations] (Mancia and others 2007)

Diet control in developing countries remains a great challenge. The diet is highly linked to the population culture, to the food conservation, cooking, and other existing infrastructures. Salt reduction measures may be difficult in population using it for food conservation. The 
restructured diets like promoted in Dietary Approaches to Stop Hypertension (DASH) (Sacks and others 1999; Svetkey and others 1999), may not apply to other low resource settings because those measures require structures of preparation, conservation and other infrastructures and resources which are not available. Therefore, preventive measures must be based on available food locally, and take into account the food and cooking habits of the population. All lifestyle modifications must emphasize the role of regular physical activity.

Another important measure to promote is the regular check of blood pressure for all (also young) adult people, in contrast to western countries where this measure is taken above a certain age.

\section{Pharmacological treatment}

The pharmacological treatment of hypertension includes several classes of anti-hypertensive drugs (Brewster and others 2004). The 5 main classes with proven effect on hard endpoints are [1] beta-blockers (BB), [2] diuretics (DIU), [3] calcium channel blockers (CCB), [4] angiotensin converting enzyme inhibitors (ACEI) and [5] angiotensin receptor blockers (ARB). Additional classes also used are centrally acting drugs, peripheral sympatholytics and direct vasodilators. The WHO recommends only four drug classes (BB, DIU, CCB and ACEI) from the five first-line classes on its essential drug list (World Health Organization 2007).

Most surveys evaluating the prescribing behaviours of practising physicians revealed that monotherapy is less preferred (one third of cases) versus polypharmacy (Anthierens and others 2010; O'Riordan and others 2008; Pittrow and others 2004). In monotherapy, betablockers have been found the drugs of choice prescribed at the level of primary health care centres in many places. Among the various beta-blockers that are approved worldwide for the treatment of hypertension, cardioselective beta-blockers atenolol and metoprolol and the non-selective beta-blocker propranolol are the commonly used. Although advocated by current guidelines, the diuretics are the not often given. In the Polypharmacy group, of combinations given as first-line nearly always include diuretics. They are combined with CCBs or ACEIs or other diuretics.

Overall the prescribers behaviour is far from homogenous, and the existence of international guidelines may not help a lot, if they are not adapted to local or specific situations.

\section{First-line drugs in hypertension}

As far as the first-line drug in treatment of hypertension is concerned, the opening debate may be the choice between monotherapy versus combination therapy as first line for the treatment of uncomplicated arterial hypertension. However, this debate seems less supported as it may be more cost-effective to start with a single drug and try to control the blood pressure combined with non-pharmacological treatment.

Historically the selection of the first-line drug remains debatable (Lindholm and others 2005). Since $1993 \mathrm{WHO} / \mathrm{ISH}$ guidelines sub-committee recommended that diuretics, betablockers, ACE inhibitors, calcium channel blockers and alpha-blockers are first-line drugs suitable for treatment of patients with hypertension. This view was again endorsed by the guidelines subcommittee of WHO/ISH in 1999 with the addition of a new class of antihypertensive, angiotensin II receptor antagonists. The United States JNC VI (Johnson 
2008)in May 2003 and British Hypertension Society guidelines(Johnson 2008) both recommended low-dose diuretics and beta-blockers as first-line treatment unless there are compelling contraindications or compelling indications for other drug classes. These differences are of considerable importance, because pharmaceutical companies are inevitably keen to promote the more liberal international (WHO/ISH) guidelines even in countries with national guidelines that recommend a different policy (Ho and others 2010; Johnson 2008).

The aim of this section will not be to prolong the debate but to extract a clear message and recommendations from existing information.

To suggest any other first-line drug, it is important to focus on comparative analyses of cardiovascular outcomes, efficacy in reducing blood pressure (BP), adverse effects, contraindications and cost.

What then should be our final choice for routine first-line antihypertensive treatment? Some patients have compelling indications or contraindications for one drug class or another, but the vast majority do not. For these patients the trial evidence would not support the use of selective alpha-blockers or calcium channel blockers as routine first-line treatment (Jackson and Ramsay 2002). The evidence would justify the use of low-dose diuretics, beta-blockers, or ACE inhibitors as routine first-line treatment, with nothing important to choose between them. When there is really nothing to choose between drugs, it is self-evident that the cheapest drug should be preferred. In most health care systems, that will be a low dose of a thiazide diuretic (Jackson and Ramsay 2002).

Coming back to low resource settings, evidences support the use of thiazide diuretics as first line and in monotherapy as well, followed if uncontrolled blood pressure by association with a very small dose of Reserpine where the affordability is very low (Twagirumukiza and Van Bortel 2011). In places where the treatment affordability is optimum, the diuretics can be associated to CCBs or ACEIs or other diuretics (Twagirumukiza and Van Bortel 2011), or to BBs in situations where their efficacy has been documented and approved (Fig.1).

Decrease of BP induced by antihypertensive drugs

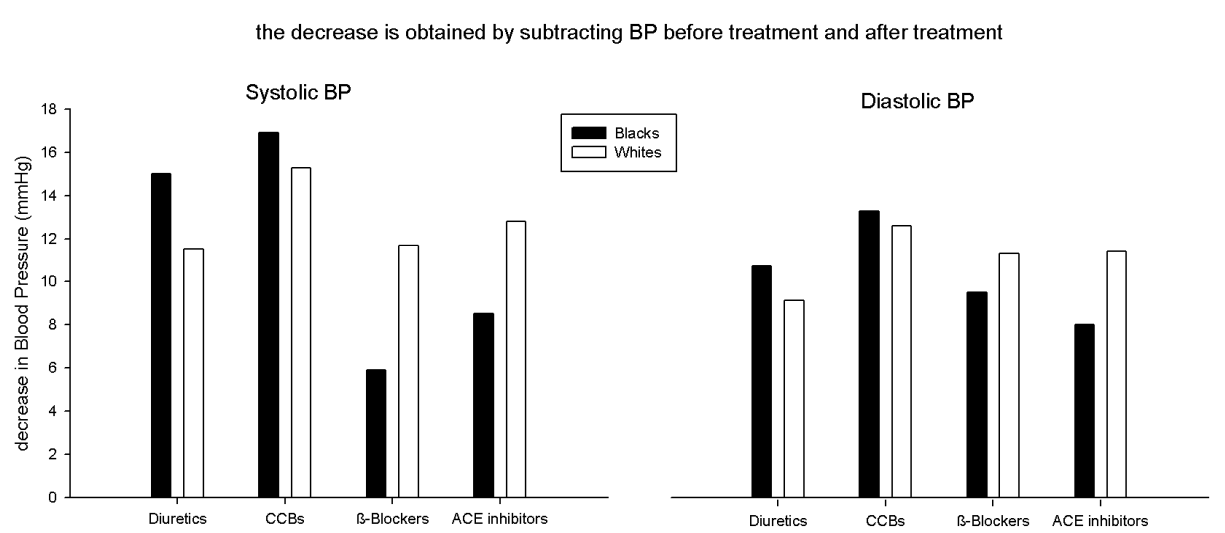

CCBs: calcium channel blockers; BP: blood pressure.

Fig. 1. Decrease in BP with antihypertensive drug treatments in Black/Whites [adapted from Brewster et al(Brewster and others 2004)] 


\subsection{The use of guidelines: Applicable for all?}

There are 3 main international guidelines suggested for the management of hypertension in the world : (1) the $2003 \mathrm{WHO} / \mathrm{ISH}$ Statement on Management of Hypertension(Whitworth 2003); (2) the European guideline, issued by European Society of Hypertension (ESH) and European society of cardiology (ESC): the 2007 ESH/ESC guidelines (Mancia and others 2007) and (3) the United States of America (US) guideline, issued by the Joint National Committee on Prevention, Detection, Evaluation, and Treatment of High Blood Pressure: the 2003 JNC-7 report (Chobanian and others 2003). Besides those main guidelines others documents and reports have been published to help in management of hypertension in particular settings, including: (1) the consensus statement of the Hypertension in AfricanAmericans working group of the International Society on Hypertension in Blacks (Douglas and others 2003), and (2) the 2002 WHO Cardiovascular Risk Management Package in Lowand Medium-Resource Settings (World Health Organization (WHO) 2002).

However, those international guidelines may not be applicable in all low resources settings as specificities can exist in the concerned population. For instance the content of nonpharmacological treatment that is mainly based on lifestyle change and promoted by a patient education package remains similar in western developed countries and developing countries. Nevertheless, a difference in outcomes can be expected from the high illiteracy rate in developing countries that may require different educational methods. Moreover, the population cultures and the real way of living (activities, historic habits like salt intake, etc) must be taken into account.

This chapter will provide a suggested algorithm for management of hypertension from the community level and with emphasis on the primary health care setting and public health perspective.

Whatever guideline considered, we cannot assume its applicability to all regions, even if they have been drafted on regional basis. For instance, the limited resources devoted toward health care in many developing countries limit the number of health facilities and existence of health insurance schemes (Ndiaye and others 2007). In this setting, cases of malignant hypertension, with target organ damage are frequent (Mensah and others 1994). Pooled data from inhospital studies published between 1998 and 2008, show that the most frequent complication reported downward are heart failure, renal failure, stroke and coronary heart disease (CHD) (Twagirumukiza and Van Bortel 2011).

Additionally, although the benefit of treatment is established(Brewster and others 2004), the treatment cost and accessibility must be more emphasized in developing countries (Twagirumukiza and others 2010).

Also, ethnic differences have been described also in drug response(Johnson 2008) in Caucasians versus blacks, but since there is limited clinical trial data from the African region, it is not fully clear whether the differences observed in USA can be fully extrapolated to African or other ethnic groups. Nevertheless, the available data from studies conducted in sub-Saharan Africa, confirm notable differences in response to $\beta$-blockers (Preston and others 1998), ACE inhibitors (Sareli and others 2001), and angiotensin receptor blockers (Wright, Jr. and others 2005), and stress the efficacy of diuretics, particularly thiazides (Wright, Jr. and others 2008). A meta-analysis, published in 2004 (Brewster and others 2004), 
evaluating 15 clinical trials published between 1984 and 1998 reported differences in antihypertensive response between blacks and whites of comparable groups, highlights the fact that whites tend to respond to all the drug classes (Figure 1) whereas blacks generally respond better than whites to diuretics and calcium channel blockers, and whites respond better than blacks to ACE inhibitors and $\beta$-blockers (Opie and Seedat 2005).

In many developing countries, two other aspects must be added in all hypertension treatment strategies: the quality of the drug and its price, which influence the efficacy of the treatment, its accessibility and adherence. Contrary to western countries where the drugs registration process and other related regulations are meticulous, in sub-Saharan Africa the quality of drug is not checked at entrance (Caudron and others 2008), the drug market is not fully controlled (Andriollo $\mathrm{O}$ and others 1998), registration processes are very often lacking (Caudron and others 2008) and the pharmacovigilance systems are not yet established everywhere. Moreover, the storage in tropical conditions with high humidity and high temperature deteriorate the drugs potency and/or bioavailability (Twagirumukiza and others 2009a).

The big contrast between western and sub-Saharan Africa settings in this area is the affordability to the treatment. In sub-Saharan Africa the price of the majority of antihypertensive drugs is higher than indicated in the International Drugs Prices Indicator Guide (IDPIG) (Management Sciences for Health (MSH) and World Health Organization (WHO) 2007), and treatments with an antihypertensive drug are in general cheaper when the drug is on the National Essential Medicine List (NEML). Drug price monitoring in every country, putting drugs on NEML, and setting up regulations on the drug market, are the main actions to reduce and/or stabilize the prices of drugs (Health Action International 2008) and to improve the affordability and accessibility to the hypertension treatment.

\subsection{Public health perspective}

Based on available data and the 2002 WHO Cardiovascular Risk Management Package in Low- and Medium-Resource Settings(World Health Organization (WHO) 2002), a set of algorithms have been proposed (Twagirumukiza and Van Bortel 2011) for hypertension management in low resources settings and particularly in sub-Saharan Africa. The following 2 algorithms (Figure $2 \& 3$ ) are extracted from the full set of them. Since every region has its own disparities between countries, those algorithm have flexibility to be adapted according to the country situation and it involves the use of total cardiovascular risk assessment, based on WHO cardiovascular risk assessment charts (Mendis and others 2007).

The entry point is the suggestion of measuring blood pressure in all adults persons (25 years and above) at community level (commonly at the Community Health Worker/Advisor post)

The second step concerns those people detected with severe hypertension (sent immediately to the near health center) or those with hypertension grade 1 and 2 not responding to nonpharmacological treatment. Emphasis is to be made on the length of the follow up period on non-pharmacological treatment which is a maximum of 3 months for grade 2 hypertension and 6 months for the grade 1 hypertension. 


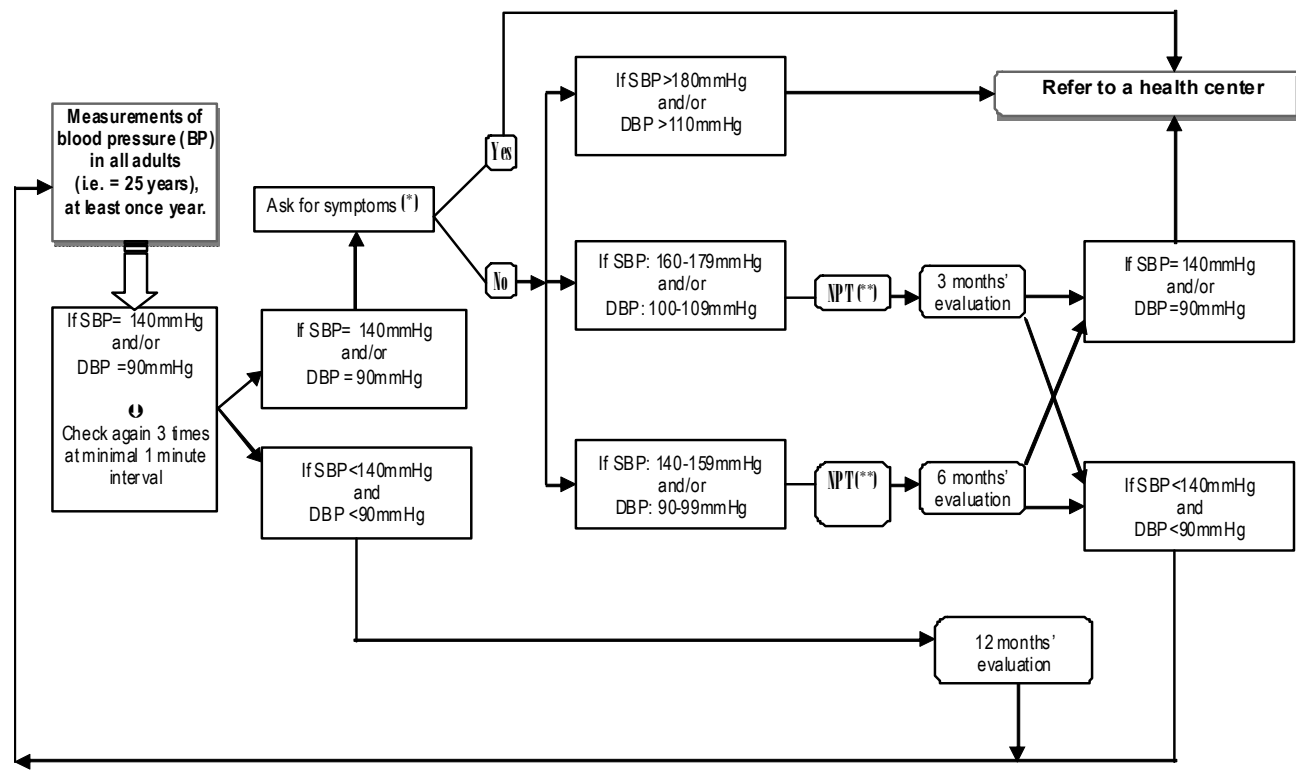

Legends: NPT: Non-pharmacological treatment; SBP: Systolic blood pressure; DBP: Diastolic blood pressure

Notes:(*) Symptoms to ask (Yes means the person answers yes at least to one of following questions):

- Shortness of breath on small exercise (like climbing a small distance, walking, etc)

- Both feet swollen.

$(* *)$ Non pharmacological treatment (NPT) includes:

- Stop smoking (keep in mind all kind of tobacco use)

- Overweight reduction and recommendation of a regular physical activity

- Dietetic measures: (Salt reduction, promote fresh fruits and vegetables intake, fatty food limitation, minimizing alcohol intake)

Fig. 2. Hypertension management strategy at the community level: At least, where a community health advisor/worker is available. (adapted from Twagirumukiza $\mathrm{M}$ et al, 2011)(Twagirumukiza and Van Bortel 2011) 


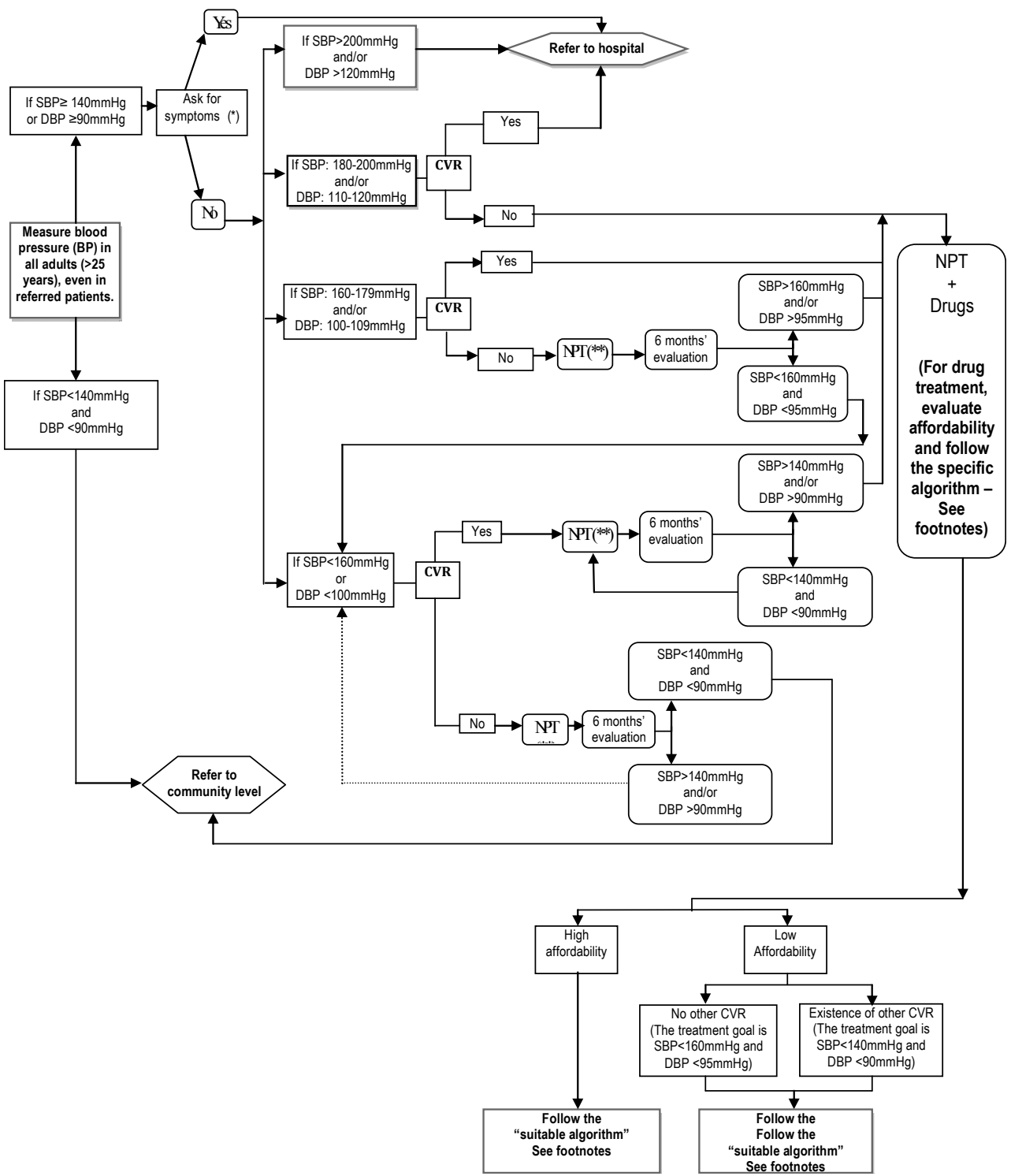

Legends: ECG= Electrocardiography; NPT: Non-pharmacological treatment; CVR: Cardiovascular risk factors; SBP: Systolic blood pressure; DBP: Diastolic blood pressure

Notes: [1] Minimal equipment: urine sticks for protein and glucose and preferentially a standard Electrocardiography.

[2] At CVR evaluation "Yes" means at least one cardiovascular risk factor is present; the cardiovascular factors to detect are:

a. Proteinuria (using dipsticks)

b. Glucosuria (using dipsticks). If positive follow also instructions for diabetes. 
c. The left ventricular hypertrophy $(\mathrm{LVH})$ on ECG; defined by a Cornell product parameter (positive if $>2440 \mathrm{~mm}^{*} \mathrm{msec}$ ). The parameter is calculated as follows:

- $\quad$ Cornell product $=(\mathrm{RaVL}+\mathrm{SV} 3) \times \mathrm{QRS}$ duration (meaning the product of $\mathrm{QRS}$ duration with the sum of the R wave in lead "aVL" and the "S" wave in lead "V3"). The RaVL, SV3, QRS and V3 being ECG waves.

- $\quad$ To measure QRS duration on ECG, recorded at a speed of $25 \mathrm{~mm} / \mathrm{sec}$ :

- Principles:

- $1 \mathrm{mV}=10 \mathrm{~mm}$ in the vertical direction.

- $\quad$ Each small $1-\mathrm{mm}$ square represents $0.04 \mathrm{sec}(40 \mathrm{msec})$ in time and $0.1 \mathrm{mV}$ in voltage.

- QRS duration: counting 1-mm square cell of the ECG, paper corresponding to the beginning and the end of QRS complex (horizontally), and then multiply the number by $40 \mathrm{msec}$.

- $\quad \mathrm{R}$ and $\mathrm{S}$ wave voltage are obtained by counting the number of 1-mm square cell (vertically) corresponding to the wave height (amplitude).

[3] The sentence "Follow the suitable algorithm- See footnotes" at the end of fig 3 refers to the algorithm which can be found in subsequent publication (not given here).

Whet it refers to the patient affordability, this can be evaluated based on patient-doctor communication but also to the socio-economic data provided in his medical record (file) and on patient interview.

[4] The $\left(^{*}\right)$ and $\left(^{* *}\right)$ signs refer to the same legend as in figure 1 .

Fig. 3. Hypertension management algorithm at the health centre: the first step (adapted from Twagirumukiza M et al, 2011)(Twagirumukiza and Van Bortel 2011)

\subsection{Challenges and opportunities}

Currently in many developing countries the global health initiatives and governments commitment to tackle the non-communicable diseases (De Maeseneer J. and others 2011) provide an optimistic development which will enhance the management of chronic diseases in general and hypertension in particular.

The health care systems are constantly improving as the primary health care (PHC) programs are starting in various regions (De Maeseneer J 2009). Certainly the Primary Health Care (PHC)-in line with recommendations of the World Health Report 2008 (De Maeseneer J 2009), may play an important role in implementation of all chronic disease treatment strategies. Nowadays international partners put valuable efforts into training of family physicians in developing and particularly in African countries (De Maeseneer J 2009). Most of those family physicians are working in the district health hospital. However, in the future, they are intended to be located in primary health care centers and when a primary health care centre has a family physician, the management algorithm should be adapted, as referral to the hospital will be less needed.

About the drug quality (Twagirumukiza and others 2009a) and drug market regulations, it is important to mention that during recent years, there have been efforts to strengthen regulatory systems and the World Health Organization (WHO) has comprehensively assessed more than 20 regulatory authorities in sub-Saharan Africa and in Latina America, south Asia and other developing regions. WHO and others initiatives have trained a number of regulatory officials to strengthen and harmonize the drugs regulatory processes. Even if it's a long way to go to have national regulators and pharmacovigilance centres fully operational in sub-Saharan Africa countries, things have started moving in the right direction. WHO and international donors have also increasingly invested both in 
monitoring the quality of products and in building up functional quality control laboratories through the WHO respective prequalification program.

Finally, the important cross-cutting and global issues should be considered in all thinking stages of setting up the treatment of hypertension: people centred care, continuity of health care, adherence to treatment, drug interactions, contra-indications and comorbidities, and the essential broad debate of equity in health care.

\section{Conclusions}

Although it is important to consider the current knowledge of medicine for the treatment of hypertension, particular consideration should be given to cost-effectiveness and affordability of antihypertensive medicines in primary health care settings of the developing countries. This consideration is justified because many low and middle income countries have severe resource constraints and available resources currently do not allow to treat all patients according to some international guidelines. Therefore, strategies have to be developed to maximally reduce risk for and from hypertension within the limited budget. Such strategy should take into account many local socio-economic and demographic particularities. The hypertension management strategy must be based on patient's cardiovascular risk and not only on his blood pressure level. Additionally the common sense says that for the same result and efficacy the cheapest is the best choice. Therefore it's obvious that the drug prices and quality details must constitute an added criterion when choosing an antihypertensive agent. Developing countries should be encouraged to establish a list with medicine prices using the real patient price, and this list has to be updated at least every year, and the prescribers should be encouraged to choose the cheapest between the available drugs which fulfil the quality criteria.

Beyond that, the management of hypertension in primary health care settings suppose a complete rebuild of health care systems and empowering of the community. The detection and monitoring should be done at community levels and early treatment at primary health care level. As already repeated by many authors, the efforts to effectively improve the control of hypertension should be based on a patient-centred care concept, rather than disease centred care. This suppose a thorough understanding of the characteristics of patients, the dynamics of the health care system and, most importantly, on the work and function of the primary care physician as the gatekeeper.

\section{References}

[1] Ambrose JA, Barua RS. 2004. The pathophysiology of cigarette smoking and cardiovascular disease: an update. J Am Coll Cardiol 43(10):1731-7.

[2] Andriollo O, Machuron L, Videau JY, Abelli C, Plot S, Muller D. 1998. Supplies for humanitarian aid and development countries: The quality of essential multisources drugs. Sciences et Techniques Pharmaceutiques (STP Pharma Pratiques) 8(2):13755.

[3] Anthierens S, Tansens A, Petrovic M, Christiaens T. 2010. Qualitative insights into general practitioners views on polypharmacy. BMC Fam Pract 11:65.

[4] Appel LJ, Champagne CM, Harsha DW, Cooper LS, Obarzanek E, Elmer PJ, Stevens VJ, Vollmer WM, Lin PH, Svetkey LP, Stedman SW, Young DR. 2003. Effects of 
comprehensive lifestyle modification on blood pressure control: Main results of the PREMIER clinical trial. Journal of the American Medical Association 289(16):208393.

[5] Birkett NJ. 1997. The effect of alternative criteria for hypertension on estimates of prevalence and control. J Hypertens 15(3):237-44.

[6] Bovet P, Ross AG, Gervasoni JP, Mkamba M, Mtasiwa DM, Lengeler C, Whiting D, Paccaud F. 2002. Distribution of blood pressure, body mass index and smoking habits in the urban population of Dar es Salaam, Tanzania, and associations with socioeconomic status. International Journal of Epidemiology 31(1):240-7.

[7] Brewster LM, Van Montfrans GA, Kleijnen J. 2004. Systematic review: Antihypertensive drug therapy in black patients. Annals of Internal Medicine 141(8):614-27.

[8] Cappuccio FP, Plange-Rhule J, Phillips RO, Eastwood JB. 2000. Prevention of hypertension and stroke in Africa. Lancet 356(9230):677-8.

[9] Caudron JM, Ford N, Henkens M, Mace C, Kiddle-Monroe R, Pinel J. 2008. Substandard medicines in resource-poor settings: a problem that can no longer be ignored. Tropical Medicine and International Health 13(8):1062-72.

[10] Chalmers J, MacMahon S, Mancia G, Whitworth J, Beilin L, Hansson L, Neal B, Rodgers A, Ni MC, Clark T. 1999. 1999 World Health Organization-International Society of Hypertension Guidelines for the management of hypertension. Guidelines subcommittee of the World Health Organization. Clin Exp Hypertens 21(5-6):1009-60.

[11] Chemla D. 2006. Factors which may influence mean arterial pressure measurement. Can J Anaesth 53(4):421-2.

[12] Chobanian AV, Bakris GL, Black HR, Cushman WC, Green LA, Izzo JL, Jr., Jones DW, Materson BJ, Oparil S, Wright JT, Jr., Roccella EJ. 2003. The Seventh Report of the Joint National Committee on Prevention, Detection, Evaluation, and Treatment of High Blood Pressure: the JNC 7 report. Journal of the American Medical Association 289(19):2560-72.

[13] Christiaens T. 2008. Cardiovascular risk tables. BMJ 336(7659):1445-6.

[14] Cooper RS, Rotimi CN, Kaufman JS, Muna WF, Mensah GA. 1998. Hypertension treatment and control in sub-Saharan Africa: The epidemiological basis for policy. British Medical Journal 316(7131):614-7.

[15] De Maeseneer J. 2009. Primary Health Care in Africa: Now more then ever! Afr J Prm Health Care Fam Med 1(1):112-5.

[16] De Maeseneer J., Roberts RG, Demarzo M, Heath I, Sewankambo N, Kidd MR, van WC, Egilman D, Boelen C, Willems S. 2011. Tackling NCDs: a different approach is needed. Lancet.

[17] Dominguez LJ, Galioto A, Ferlisi A, Pineo A, Putignano E, Belvedere M, Costanza G, Barbagallo M. 2006. Ageing, lifestyle modifications, and cardiovascular disease in developing countries. Journal of Nutrition, Health \& Aging 10(2):143-9.

[18] Douglas JG, Bakris GL, Epstein M, Ferdinand KC, Ferrario C, Flack JM, Jamerson KA, Jones WE, Haywood LJ, Maxey R, Ofili EO, Saunders E, Schiffrin EL, Sica DA, Sowers JR, Vidt DG. 2003. Management of high blood pressure in African Americans: consensus statement of the Hypertension in African Americans Working Group of the International Society on Hypertension in Blacks. Archives of Internal Medicine 163(5):525-41. 
[19] Fields LE, Burt VL, Cutler JA, Hughes J, Roccella EJ, Sorlie P. 2004. The burden of adult hypertension in the United States 1999 to 2000: a rising tide. Hypertension 44(4):398-404.

[20] Gaziano TA. 2005. Cardiovascular disease in the developing world and its cost-effective management. Circulation 112(23):3547-53.

[21] Health Action International, HAI. Monitoring medicine prices, availability and affordability : pilot countries' reports. HAI 2008;Available from: URL: http://www.haiweb.org/medicineprices/. Accessed on: December 20, 2011

[22] Ho PM, Zeng C, Tavel HM, Selby JV, O'Connor PJ, Margolis KL, Magid DJ. 2010. Trends in first-line therapy for hypertension in the Cardiovascular Research Network Hypertension Registry, 2002-2007. Arch Intern Med 170(10):912-3.

[23] Jackson PR, Ramsay LE. 2002. First-line treatment for hypertension. Eur Heart J 23(3):179-82.

[24] Jha P, Chaloupka F. 1999. Tobacco control in developing countries. On behalf of The Human Development Network, the World Bank, and the Economics Advisory Service, World Health Organization. New York: Oxford University Press.

[25] John KJ Li. 2000. The arterial circulation : physical principals and clinical application. Piscataway, New Jersey, USA: Humana Press. 1 p.

[26] Johnson JA. 2008. Ethnic differences in cardiovascular drug response: Potential contribution of pharmacogenetics. Circulation 118(13):1383-93.

[27] Kearney PM, Whelton M, Reynolds K, Muntner P, Whelton PK, He J. 2005. Global burden of hypertension: analysis of worldwide data. Lancet 365(9455):217-23.

[28] Khosla N, Black HR. 2006. Expanding the definition of hypertension to incorporate global cardiovascular risk. Curr Hypertens Rep 8(5):384-90.

[29] Lawes CM, Vander HS, Rodgers A. 2008. Global burden of blood-pressure-related disease, 2001. Lancet 371(9623):1513-8.

[30] Lindholm LH, Carlberg B, Samuelsson O. 2005. Should beta blockers remain first choice in the treatment of primary hypertension? A meta-analysis. Lancet 366(9496):154553.

[31] Lopez AD, Mathers CD, Ezzati M, Jamison DT, Murray CJ. 2006. Global and regional burden of disease and risk factors, 2001: systematic analysis of population health data. Lancet 367(9524):1747-57.

[32] MacDonald TM, Morant SV. 2008. Prevalence and treatment of isolated and concurrent hypertension and hypercholesterolaemia in the United Kingdom. Br J Clin Pharmacol 65(5):775-86.

[33] Management Sciences for Health (MSH), World Health Organization (WHO). 2007. International drug price indicator guide 2007. 2007 ed. MSH, WHO. 1 p.

[34] Mancia G, de BG, Dominiczak A, Cifkova R, Fagard RH, Germano G, Grassi G, Heagerty AM, Kjeldsen SE, Laurent S, Narkiewicz K, Ruilope L, Rynkiewicz A, Schmieder RE, Boudier HA, Zanchetti A, Vahanian A, Camm J, De CR, Dean V, Dickstein K, Filippatos G, Funck-Brentano C, Hellemans I, Kristensen SD, McGregor K, Sechtem U, Silber S, Tendera M, Widimsky P, Zamorano JL, Erdine S, Kiowski W, Gabiti-Rosei E, Ambrosioni E, Lindholm LH, Viigimaa M, Adamopoulos S, Gabiti-Rosei E, Ambrosioni E, Bertomeu V, Clement D, Erdine S, Farsang C, Gaita D, Lip GY, Mallion JM, Manolis AJ, Nilsson PM, O'Brien E, Ponikowski P, Redon J, Ruschitzka F, Tamargo J, Van Zwieten P, Waeber B, 
Williams B. 2007. 2007 Guidelines for the Management of Arterial Hypertension: The Task Force for the Management of Arterial Hypertension of the European Society of Hypertension (ESH) and of the European Society of Cardiology (ESC). Journal of Hypertension 25(6):1105-87.

[35] Mendis S, Lindholm LH, Mancia G, Whitworth J, Alderman M, Lim S, Heagerty T. 2007. World Health Organization (WHO) and International Society of Hypertension (ISH) risk prediction charts: assessment of cardiovascular risk for prevention and control of cardiovascular disease in low and middle-income countries. J Hypertens 25(8):1578-82.

[36] Mensah GA. 2003. A heart-healthy and "stroke-free" world through policy development, systems change, and environmental supports: a 2020 vision for subSaharan Africa. Ethn Dis 13(2 Suppl 2):S4-12.

[37] Mensah GA, Barkey NL, Cooper RS. 1994. Spectrum of hypertensive target organ damage in Africa: a review of published studies. Journal of Human Hypertension 8(11):799-808.

[38] Mufunda J, Rufaro Chatora, Yustina Ndambakuwa, Peter Nyarango ea. 2006. Emerging Non-Communicable Disease Epidemic in Africa: Preventive Measures from the WHO Regional Office for Africa. Ethn Dis 16(2):521-6.

[39] Murray CJ, Lopez AD. 1997. Mortality by cause for eight regions of the world: Global Burden of Disease Study. Lancet 349(9061):1269-76.

[40] Ndiaye P, Soors W, Criel B. 2007. Editorial: a view from beneath: Community health insurance in Africa. Tropical Medicine and International Health 12(2):157-61.

[41] Nichols WW., O'Rourke MF., Vlachopoulos C. 2011. McDonald's Blood Flow in Arteries: Theoretical, Experimental and Clinical Principles. Oxford Univ Pr.

[42] O'Riordan S, Mackson J, Weekes L. 2008. Self-reported prescribing for hypertension in general practice. J Clin Pharm Ther 33(5):483-8.

[43] Opie LH, Seedat YK. 2005. Hypertension in sub-Saharan African populations. Circulation 112(23):3562-8.

[44] Papadopoulos DP, Makris TK. 2007. Masked hypertension definition, impact, outcomes: a critical review. J Clin Hypertens (Greenwich ) 9(12):956-63.

[45] Pestana JA, Steyn K, Leiman A, Hartzenberg GM. 1996. The direct and indirect costs of cardiovascular disease in South Africa in 1991. South African Medical Journal 86(6):679-84.

[46] Pittrow D, Kirch W, Bramlage P, Lehnert H, Hofler M, Unger T, Sharma AM, Wittchen HU. 2004. Patterns of antihypertensive drug utilization in primary care. Eur J Clin Pharmacol 60(2):135-42.

[47] Preston RA, Materson BJ, Reda DJ, Williams DW, Hamburger RJ, Cushman WC, Anderson RJ. 1998. Age-race subgroup compared with renin profile as predictors of blood pressure response to antihypertensive therapy. Department of Veterans Affairs Cooperative Study Group on Antihypertensive Agents. Journal of the American Medical Association 280(13):1168-72.

[48] Reddy KS, Yusuf S. 1998. Emerging epidemic of cardiovascular disease in developing countries. Circulation 97(6):596-601.

[49] Roger VL., Go AS., Lloyd-Jones DM., Adams RJ, Berry JD, Brown TM, Carnethon MR, Dai S, de SG, Ford ES, Fox CS, Fullerton HJ, Gillespie C, Greenlund KJ, Hailpern SM, Heit JA, Ho PM, Howard VJ, Kissela BM, Kittner SJ, Lackland DT, Lichtman 
JH, Lisabeth LD, Makuc DM, Marcus GM, Marelli A, Matchar DB, McDermott MM, Meigs JB, Moy CS, Mozaffarian D, Mussolino ME, Nichol G, Paynter NP, Rosamond WD, Sorlie PD, Stafford RS, Turan TN, Turner MB, Wong ND, WylieRosett J. 2011. Heart disease and stroke statistics-2011 update: a report from the American Heart Association. Circulation 123(4):e18-e209.

[50] Sacks FM, Appel LJ, Moore TJ, Obarzanek E, Vollmer WM, Svetkey LP, Bray GA, Vogt TM, Cutler JA, Windhauser MM, Lin PH, Karanja N. 1999. A dietary approach to prevent hypertension: a review of the Dietary Approaches to Stop Hypertension (DASH) Study. Clinical Cardiology 22(7 Suppl):III6-10.

[51] Sareli P, Radevski IV, Valtchanova ZP, Libhaber E, Candy GP, Den HE, Libhaber C, Skudicky D, Wang JG, Staessen JA. 2001. Efficacy of different drug classes used to initiate antihypertensive treatment in black subjects: results of a randomized trial in Johannesburg, South Africa. Archives of Internal Medicine 161(7):965-71.

[52] Svetkey LP, Sacks FM, Obarzanek E, Vollmer WM, Appel LJ, Lin PH, Karanja NM, Harsha DW, Bray GA, Aickin M, Proschan MA, Windhauser MM, Swain JF, McCarron PB, Rhodes DG, Laws RL. 1999. The DASH Diet, Sodium Intake and Blood Pressure Trial (DASH-sodium): rationale and design. DASH-Sodium Collaborative Research Group. Journal of American Dietetic Association 99(8 Suppl):S96-104.

[53] Twagirumukiza M, Annemans L, Kips JG, Bienvenu E, Van Bortel LM. 2010. Prices of antihypertensive medicines in sub-Saharan Africa and alignment to WHO's model list of essential medicines. Trop Med Int Health 15(3):350-61.

[54] Twagirumukiza M, Cosijns A, Pringels E, Remon JP, Vervaet C, Van BL. 2009a. Influence of tropical climate conditions on the quality of antihypertensive drugs from Rwandan pharmacies. Am J Trop Med Hyg 81(5):776-81.

[55] Twagirumukiza M, De Bacquer D, Kips J, vander Stichele R, De Backer G, Van Bortel LM. 2009b. Hypertension in sub-Saharan Africa (SSA): Low Prevalence, But High Risk. J Hypertens 27:S410.

[56] Twagirumukiza M, De BD, Kips JG, de BG, Stichele RV, Van Bortel LM. 2011. Current and projected prevalence of arterial hypertension in sub-Saharan Africa by sex, age and habitat: an estimate from population studies. J Hypertens 29(7):1243-52.

[57] Twagirumukiza M, Van Bortel LM. 2011. Management of hypertension at the community level in sub-Saharan Africa (SSA): towards a rational use of available resources. J Hum Hypertens 25(1):47-56.

[58] Unwin N, Setel P, Rashid S, Mugusi F, Mbanya JC, Kitange H, Hayes L, Edwards R, Aspray T, Alberti KG. 2001. Noncommunicable diseases in sub-Saharan Africa: Where do they feature in the health research agenda? Bulletin of the World Health Organization 79(10):947-53.

[59] Van Bortel LM, De BT, De BM. 2011. How to treat arterial stiffness beyond blood pressure lowering? J Hypertens 29(6):1051-3.

[60] Whitworth JA. 2003. 2003 World Health Organization (WHO)/International Society of Hypertension (ISH) statement on management of hypertension. Journal of Hypertension 21(11):1983-92.

[61] World Health Organization. 2007. The selection and use of essential medicines 2007. 15th Model list of essential medicines. WHO Technical Report Series(946):1-162. 
[62] World Health Organization, J Mackay, G.Mensah. The Atlas of Heart Disease and Stroke, 2004. WHO. 1-112. 2004. Geneva, WHO.

[63] World Health Organization (WHO). 2002. CVD-Risk Management Package for Low and Medium Resource Settings. Geneva: WHO; 7 p. Available from.

[64] World Hypertension League. 1992. Can non-pharmacological interventions reduce doses of drugs needed for the treatment of hypertension? Bulletin of the World Health Organization 70(6):685-90.

[65] Wright JT, Jr., Dunn JK, Cutler JA, Davis BR, Cushman WC, Ford CE, Haywood LJ, Leenen FH, Margolis KL, Papademetriou V, Probstfield JL, Whelton PK, Habib GB. 2005. Outcomes in hypertensive black and nonblack patients treated with chlorthalidone, amlodipine, and lisinopril. Journal of the American Medical Association 293(13):1595-608.

[66] Wright JT, Jr., Harris-Haywood S, Pressel S, Barzilay J, Baimbridge C, Bareis CJ, Basile JN, Black HR, Dart R, Gupta AK, Hamilton BP, Einhorn PT, Haywood LJ, Jafri SZ, Louis GT, Whelton PK, Scott CL, Simmons DL, Stanford C, Davis BR. 2008. Clinical outcomes by race in hypertensive patients with and without the metabolic syndrome: Antihypertensive and Lipid-Lowering Treatment to Prevent Heart Attack Trial (ALLHAT). Archives of Internal Medicine 168(2):207-17. 